\title{
Gluconeogenesis in Mouse-Liver Slices
}

\author{
BY H. A. KREBS, BRENDA M. NOTTON AND R. HEMS \\ Medical Research Council Unit for Research in Cell Metabolism, \\ Department of Biochemistry, University of Oxford
}

(Received 2 May 1966)

\begin{abstract}
1. The rate of gluconeogenesis from amino acids and other known precursors in slices of mouse liver after depletion of liver glycogen by means of phlorrhizin was high with L-lactate, pyruvate, glycerol, D-glyceraldehyde, dihydroxyacetone, D-fructose, sorbitol, xylitol, $\alpha$-glycerophosphate, alanine, proline, threonine, serine and propionate. 2. The rate was unexpectedly low or even negligible with glutamate, aspartate, other glucogenic amino acids and the intermediates of the tricarboxylic acid cycle. 3. Glutamine and asparagine gave higher rates than the corresponding amino acids but still much lower rates than kidney cortex. 4. Livers of male mice gave much lower rates than livers of female mice. Kidney cortex showed no sex difference. 5. Livers of mice fed on a low-carbohydrate diet gave the same rates as livers of mice fed on a normal diet under the test conditions, i.e. $3 \mathrm{hr}$. after an injection of phlorrhizin. 6. Much carbohydrate was formed from endogenous precursors and this was accompanied by release of ammonia and urea. 7. Gluconeogenesis in well-fed mice not treated with phlorrhizin was low. 8. Maximum rates were observed $3 \mathrm{hr}$. after phlorrhizin treatment. 9. Prolonged phlorrhizin treatment did not prevent extensive deposition of liver glycogen, after an initial depletion. 10. Gluconeogenesis in livers of mice fed on a high-fat diet was relatively low. 11. Livers of alloxan-diabetic mice had a high carbohydrate content after phlorrhizin treatment, and gluconeogenesis from endogenous sources was about twice as high as in normal animals. Added substrates had about the same effect in normal and diabetic livers.
\end{abstract}

A synthesis of carbohydrate in vitro in liver slices was first recorded by Takane (1926) and has often been studied since (Cori \& Shine, 1936; Bach \& Holmes, 1937; Cross \& Holmes, 1937; Buchanan, Hastings \& Nesbett, 1942). The rates observed, however, were very low compared with those expected from observations in the intact body. Cori \& Cori (1929) fed lactate to rats by stomach tube and measured the rate at which glycogen appeared in the liver. They observed a formation of about $30 \mu$ moles of glucose/g. wet wt. of liver $/ \mathrm{hr}$. This value is by no means indicative of the maximal capacity of the liver. The isolated perfused rat liver forms from lactate between 60 and $100 \mu$ moles of glucose/g. wet wt./hr. (Exton \& Park, 1965; Hems, Ross, Berry \& Krebs, 1966). The rates reported for rat-liver slices were very much lower.

The primary aim of the present work was to investigate systematically gluconeogenesis from various precursors in liver slices and to compare the behaviour of the liver with that of kidney cortex. Preliminary tests on several mammalian species (rat, mouse, golden hamster, rabbit, guinea pig, sheep and cattle) indicated that mouse liver gave the highest rates, and this tissue was therefore chosen for the main experiments.

\section{EXPERIMENTAL}

Animals. Swiss white mice weighing about $20 \mathrm{~g}$. were used. Their standard diet consisted of Small Laboratory Animal Diet (Spillers Ltd., Gainsborough, Lincs.). The low-carbohydrate diet contained 3 parts of casein and 1 part of margarine, and the high-fat diet 1 part of casein and 3 parts of margarine, plus vitamin and mineral supplements as described by Krebs, Bennett, de Gasquet, Gascoyne \& Yoshida (1963).

Phlorrhizin treatment. Phlorrhizin (1 g./kg. body wt.) was given freshly dissolved in $0.1 \mathrm{ml}$. of aq. $50 \%(\mathrm{v} / \mathrm{v})$ butane2,3-diol. Propane-1,2-diol, recommended as a solvent for phlorrhizin by Weissberger (1941), was avoided because it has been reported to be glucogenic (Hanzlik, Lehman, van Winkle \& Kennedy, 1939). The animal was lightly anaesthetized with ether, and the solution was injected subcutaneously into the back. The animal was then left without food and killed $3 \mathrm{hr}$. later, unless otherwise stated. During this interval much glucose was excreted in the urine.

Treatment of the tissue. The liver was removed immediately after death and cooled inside a polythene bag in ice. Slices were cut freehand by the method of Deutsch (1936) 
with a dry razor blade; they were weighed on a torsion balance. Between 50 and $90 \mathrm{mg}$. wet wt. of tissue was placed in $4 \mathrm{ml}$. of the saline medium of Krebs \& Henseleit (1932) in a conical Warburg flask and shaken for $1 \mathrm{hr}$. at $40^{\circ}$ with $\mathrm{O}_{2}+\mathrm{CO}_{2}(95: 5)$ in the gas phase. Unless otherwise stated the substrate concentration was $10 \mathrm{~mm}$. At the end of the incubation period $0.1 \mathrm{vol}$. of $3 \mathrm{~N}-\mathrm{HClO}_{4}$ was added and the contents of the cup were homogenized in a glassTeflon homogenizer. The homogenate was left for about $16 \mathrm{hr}$. in the refrigerator, during which time the glycogen went into solution. The clear supernatant obtained by centrifugation was used for the determination of glucose and glycogen. The dry weight of the tissue was determined by drying a weighed wet sample to constant weight at $110^{\circ}$.

Replacing the standard saline by other media did not increase the rate of conversion of lactate into carbohydrate. A phosphate-buffered saline (Krebs \& de Gasquet, 1964) gave almost the same value as the bicarbonate-buffered saline. Addition of bovine serum albumin $(2 \cdot 6 \%, w / v)$ was without effect. Ascites fluid, recommended by Warburg, Gawehn \& Geissler (1956) as an incubation medium, showed no advantages. Varying the quantity of slices between 40 and $200 \mathrm{mg}$. wet wt./ml. did not affect the rate of gluconeogenesis provided that the rate of shaking was rapid.

Analytical methods. Glucose was determined by the glucose-oxidase method previously described with trisphosphate buffer to prevent the hydrolysis of maltose, maltotriose and related oligosaccharides by the glucoseoxidase preparation (see Krebs, Dierks \& Gascoyne, 1964). Glycogen was determined as glucose after enzymic hydrolysis as described by Krebs et al. (1963) and the quantities of glycogen are expressed as glucose equivalents. Ammonia and urea were determined by the micro-diffusion method of Conway (1962). Glycerol was measured by the method of Garland \& Randle (1962).

\section{RESULTS}

Preformed liver carbohydrate. The accurate measurement of the net formation of carbohydrate is difficult unless the initial carbohydrate content of the liver is low. Large variations, between 300 and $1400 \mu$ moles of glucose plus glycogen $/ \mathrm{g}$. dry wt., were found in livers of well-fed mice given the same diet. These variations could be correlated with the feeding habits (see below). Frequent disturbances during the daytime, preventing the animals from sleeping and prompting them to feed, favoured carbohydrate storage, whereas quietness and darkness during the daytime caused depletion of the store. After $24 \mathrm{hr}$. starvation the value for carbohydrate had fallen to between 12 and $200 \mu$ moles/g. dry wt. As the increments caused by added substrates on incubation of slices varies with the nature of the substrate and may be as low as $10 \mu \mathrm{moles} / \mathrm{g}$. dry wt./hr. it was essential to use livers with a low initial carbohydrate content. The injection of phlorrhizin $3 \mathrm{hr}$. before killing, as described in the Experimental section, and with- holding food during this $3 \mathrm{hr}$. period had the desired effect, producing livers with between 2 and $20 \mu$ moles of carbohydrate/g. dry wt.

Rates of gluconeogenesis from various precursors. Measurements of the formation of glucose plus glycogen under standard test conditions carried out on livers of female mice fed on the standard diet, treated with phlorrhizin and killed $3 \mathrm{hr}$. later are shown in Table 1. The initial carbohydrate values were low but there was a considerable increase (about two- to three-fold) on incubation without substrate. L-Lactate, pyruvate, $\alpha$-glycerophosphate, propionate, alanine, proline, serine and threonine caused increases in the carbohydrate yield comparable in magnitude with those previously observed in rat kidney cortex. Still higher rates were obtained with substances that give triose phosphate or glucose by a relatively small number of steps (glycerol, dihydroxyacetone, D-glyceraldehyde, xylitol, fructose and sorbitol). In all experiments glucose and glycogen were determined separately but almost all the newly formed carbohydrate (85-100\%) was glucose. Unexpectedly, glutamate, aspartate and ornithine, which readily form glucose in the intact body and in the kidney cortex, were almost completely ineffective as precursors. L-Glyceraldehyde and D-lactate gave very low rates.

Isoleucine gave no significant increase. A number of other substances that also gave negative or near-negative results under the same conditions are not listed in Table 1. They are citrate, succinate, malate, fumarate, $\alpha$-oxoglutarate, L-valine, Larginine, L-histidine, mannitol, D-mannose and L-sorbose. The failure of the intermediates of the tricarboxylic acid cycle to form glucose is as surprising as that of glutamate and aspartate, in view of their effectiveness in kidney-cortex slices. As it is feasible that this failure might be due to inhibitory effects of the relatively high concentrations of the substrates, succinate and fumarate were tested at $1 \cdot 25,2.5$ and $5 \mathrm{~mm}$ but no carbohydrate was formed, although the increased negative pressure changes in the manometer vessels on the addition of succinate indicated that succinate readily underwent oxidation. In another series of tests glutamate and aspartate were compared with glutamine and asparagine (Table 2). In both cases the amides gave significantly higher rates than the amino acids but by comparison with other substrates, and especially with the reactivity of glutamate and aspartate in kidney cortex, the rates were low.

Rates very similar to those given in Table 1 were obtained when the mice were fed on the lowcarbohydrate diet before the phlorrhizin treatment (Table 3). The amounts of carbohydrate formed on incubation without substrate and with the substrates tested were not significantly different from 
Table 1. Formation of carbohydrate from various precursors by liver slices from female mice

Female mice fed on the standard diet and treated with phlorrhizin were used. Incubation was for $1 \mathrm{hr}$. The substrate concentration was $10 \mathrm{~mm}$ except for $\mathrm{D}$ - and L-glyceraldehyde where it was $5 \mathrm{~mm}$ because higher concentrations of L-glyceraldehyde were inhibitory (see also Krebs \& Lund, 1966). The results represent $\mu$ moles of glucose plus glycogen (expressed as glucose)/g. dry wt. The results are given as means \pm s.E.M. The number of observations was six except for L-lactate where it was eight. For further details see the text.

Glucose + glycogen in slices + medium ( $\mu$ moles/g. dry wt./hr.)

\begin{tabular}{|c|c|c|c|c|c|c|}
\hline \multirow[b]{2}{*}{ Substrate added } & \multirow[b]{2}{*}{$\begin{array}{c}\text { Initial } \\
\text { glucose }+ \\
\text { glycogen } \\
(\mu \text { moles/g. } \\
\text { dry wt.) }\end{array}$} & \multicolumn{2}{|c|}{ substrate } & \multicolumn{3}{|c|}{ Incubated with substrate } \\
\hline & & Found & $\begin{array}{c}\text { Increase } \\
\text { over } \\
\text { initial }\end{array}$ & Found & $\begin{array}{c}\text { Increase } \\
\text { over } \\
\text { initial }\end{array}$ & $\begin{array}{c}\text { Extra carbo- } \\
\text { hydrate due } \\
\text { to added } \\
\text { substrate }\end{array}$ \\
\hline L-Lactate & $17 \cdot 2 \pm 4 \cdot 3$ & $51 \pm 3 \cdot 8$ & $34 \pm 5 \cdot 0$ & $136 \pm 19$ & $119 \pm 15$ & $85 \pm 16$ \\
\hline D-Lactate & $2.9 \pm 0.6$ & $27 \pm 2 \cdot 4$ & $24 \pm 2 \cdot 4$ & $47 \pm 6 \cdot 8$ & $44 \pm 6 \cdot 8$ & $20 \pm 5 \cdot 4$ \\
\hline Pyruvate & $11 \cdot 9 \pm 2 \cdot 5$ & $42 \pm 2 \cdot 7$ & $30 \pm 2 \cdot 2$ & $143 \pm 11$ & $131 \pm 11$ & $101 \pm 8 \cdot 1$ \\
\hline Glycerol & $15 \cdot 7 \pm 5 \cdot 8$ & $48 \pm 7 \cdot 7$ & $32 \pm 9 \cdot 3$ & $199 \pm 5 \cdot 3$ & $183 \pm 12$ & $151 \pm 9 \cdot 2$ \\
\hline D-Glyceraldehyde & $2 \cdot 9 \pm 0 \cdot 6$ & $27 \pm 2 \cdot 4$ & $24 \pm 2 \cdot 4$ & $130 \pm 24$ & $127 \pm 24$ & $103 \pm 23$ \\
\hline L-Glyceraldehyde & $2 \cdot 9 \pm 0.6$ & $27 \pm 2 \cdot 4$ & $24 \pm 2 \cdot 4$ & $47 \pm 7 \cdot 2$ & $44 \pm 7 \cdot 2$ & $20 \pm 5 \cdot 2$ \\
\hline Dihydroxyacetone & $2 \cdot 9 \pm 0 \cdot 6$ & $27 \pm 2 \cdot 4$ & $24 \pm 2 \cdot 4$ & $144 \pm 28$ & $141 \pm 28$ & $117 \pm 26$ \\
\hline DL- $\alpha$-Glycerophosphate & $11 \cdot 8 \pm 2 \cdot 2$ & $49 \pm 3 \cdot 0$ & $37+2 \cdot 4$ & $94 \pm 9 \cdot 9$ & $82 \pm 8 \cdot 0$ & $45 \pm 8 \cdot 1$ \\
\hline D-Fructose & $17 \cdot 8 \pm 3 \cdot 2$ & $64 \pm 6 \cdot 9$ & $46 \pm 4 \cdot 8$ & $289 \pm 8 \cdot 3$ & $271 \pm 8 \cdot 1$ & $225 \pm 12$ \\
\hline Sorbitol & $17 \cdot 8 \pm 3 \cdot 2$ & $64 \pm 6 \cdot 9$ & $46 \pm 4 \cdot 8$ & $266 \pm 13$ & $248 \pm 11$ & $202 \pm 14$ \\
\hline Xylitol & $11 \cdot 4 \pm 1 \cdot 5$ & $52 \pm 5 \cdot 3$ & $41 \pm 5 \cdot 7$ & $277 \pm 10$ & $266 \pm 9 \cdot 3$ & $225 \pm 9.0$ \\
\hline Propionate & $2.9 \pm 0.6$ & $27 \pm 2 \cdot 4$ & $24 \pm 2 \cdot 4$ & $75 \pm 14$ & $72 \pm 14$ & $48 \pm 13$ \\
\hline L-Alanine & $15 \cdot 7 \pm 5 \cdot 8$ & $48 \pm 7 \cdot 7$ & $32 \pm 9 \cdot 3$ & $108 \pm 10$ & $92 \pm 5 \cdot 7$ & $60 \pm 3.9$ \\
\hline L-Aspartate & $17 \cdot 6 \pm 3 \cdot 2$ & $58 \pm 5 \cdot 4$ & $40 \pm 3 \cdot 5$ & $54 \pm 3 \cdot 3$ & $37 \pm 2 \cdot 9$ & $-4 \pm 2 \cdot 8$ \\
\hline L-Glutamate & $17 \cdot 6 \pm 3 \cdot 2$ & $58 \pm 5 \cdot 4$ & $40 \pm 3.5$ & $58 \pm 3.4$ & $41 \pm 2.9$ & $0 \pm 2 \cdot 8$ \\
\hline L-Proline & $11.9 \pm 2.5$ & $42 \pm 2 \cdot 7$ & $30 \pm 2 \cdot 2$ & $86 \pm 3 \cdot 2$ & $74 \pm 1.9$ & $44 \pm 2 \cdot 9$ \\
\hline L-Threonine & $18 \cdot 0 \pm 3 \cdot 0$ & $67 \pm 5 \cdot 7$ & $49 \pm 4 \cdot 9$ & $111 \pm 4.4$ & $93 \pm 5 \cdot 7$ & $44 \pm 4 \cdot 7$ \\
\hline L-Isoleucine & $7 \cdot 8 \pm 2 \cdot 8$ & $44 \pm 4 \cdot 8$ & $36 \pm 2 \cdot 6$ & $46 \pm 3 \cdot 3$ & $38 \pm 1.8$ & $2 \pm 2 \cdot 0$ \\
\hline L-Ornithine & $7 \cdot 8 \pm 2 \cdot 8$ & $44 \pm 4 \cdot 8$ & $36 \pm 2 \cdot 6$ & $49 \pm 4 \cdot 9$ & $41 \pm 2 \cdot 6$ & $5 \pm 1 \cdot 6$ \\
\hline L-Serine & $7 \cdot 8 \pm 2 \cdot 8$ & $44 \pm 4 \cdot 8$ & $36 \pm 2 \cdot 6$ & $84 \pm 5 \cdot 3$ & $76 \pm 4 \cdot 9$ & $40 \pm 4 \cdot 7$ \\
\hline
\end{tabular}

Table 2. Comparison of the rates of carbohydrate formation from glutamate, aspartate and their amides

The experimental conditions were as described for Table 1. The number of observations was four.

Glucose + glycogen in slices + medium ( $\mu$ moles/g. dry wt./hr.)

\begin{tabular}{|c|c|c|c|c|}
\hline \multicolumn{2}{|c|}{$\begin{array}{c}\text { Incubated without } \\
\text { substrate }\end{array}$} & \multicolumn{3}{|c|}{ Incubated with substrate } \\
\hline Found & $\begin{array}{c}\text { Increase } \\
\text { over } \\
\text { initial }\end{array}$ & Found & $\begin{array}{c}\text { Increase } \\
\text { over } \\
\text { initial }\end{array}$ & $\begin{array}{c}\text { Extra carbo- } \\
\text { hydrate due } \\
\text { to added } \\
\text { substrate }\end{array}$ \\
\hline $44 \pm 3 \cdot 1$ & $30 \pm 2 \cdot 6$ & $\begin{array}{l}58 \pm 5 \cdot 9 \\
83 \pm 8 \cdot 5 \\
52 \pm 4 \cdot 8 \\
71 \pm 9 \cdot 6\end{array}$ & $\begin{array}{l}44 \pm 6 \cdot 1 \\
69 \pm 8 \cdot 7 \\
38 \pm 4 \cdot 7 \\
57 \pm 8 \cdot 6\end{array}$ & $\begin{array}{r}14 \pm 3 \cdot 7 \\
39 \pm 7 \cdot 0 \\
8 \pm 1 \cdot 2 \\
27 \pm 7 \cdot 6\end{array}$ \\
\hline
\end{tabular}

those obtained with mice fed on the standard diet. In this respect mouse liver differs from rat kidney cortex (Krebs et al. 1963).

Sex differences in gluconeogenesis. There was a distinct difference between the gluconeogenic capacity of the livers of male and female animals (compare Tables 1 and 4). Though the initial carbohydrate content of the livers and the increases 
that occurred on incubation without substrate were virtually the same in both sexes the effects produced by the addition of pyruvate, glycerol, proline, alanine were in males only about $50 \%$ of that in females. With L-lactate male liver gave $60 \%$ of the rate given with female liver. With fructose, sorbitol and xylitol the rate was $71-86 \%$.

In contrast with liver, kidney cortex showed no regular sex differences with respect to gluconeogenic capacity (Table 5). With propionate male animals seemed to give higher values; with sorbitol females gave higher values. With 14 other substrates there were no significant differences.

Precursors of carbohydrate formed without added substrate. In the experiments recorded in Tables $1,2,3$ and 4 the formation of carbohydrate in slices

Table 3. Formation of carbohydrate from various precursors by liver slices from female mice fed on a low carbohydrate diet

Except for the diet, the experimental conditions were as described for Table 1. For the composition of the low-carbohydrate diet see the Experimental section. The diet was given for 4-12 days. The number of observations was six except for L-lactate where it was seven.

\begin{tabular}{|c|c|c|c|c|c|c|}
\hline \multirow[b]{3}{*}{ Substrate added } & \multirow[b]{3}{*}{$\begin{array}{c}\text { Initial } \\
\text { glucose }+ \\
\text { glycogen } \\
\text { ( } \mu \text { moles/g. } \\
\text { dry wt.) }\end{array}$} & \multicolumn{5}{|c|}{ Glucose + glycogen in slices + medium ( $\mu$ moles/g. dry wt. $/ \mathrm{hr})}$. \\
\hline & & \multicolumn{2}{|c|}{$\begin{array}{c}\text { Incubated without } \\
\text { substrate }\end{array}$} & \multicolumn{3}{|c|}{ Incubated with substrate } \\
\hline & & Found & $\begin{array}{c}\text { Increase } \\
\text { over } \\
\text { initial }\end{array}$ & Found & $\begin{array}{c}\text { Increase } \\
\text { over } \\
\text { initial }\end{array}$ & $\begin{array}{l}\text { Extra carbo- } \\
\text { hydrate due } \\
\text { to added } \\
\text { substrate }\end{array}$ \\
\hline L-Lactate & $17 \cdot 5 \pm 4 \cdot 4$ & $56 \pm 9 \cdot 9$ & $38 \pm 4 \cdot 8$ & $138 \pm 11$ & $120 \pm 13$ & $82 \pm 9.5$ \\
\hline Pyruvate & $18 \cdot 9 \pm 7 \cdot 9$ & $59 \pm 6 \cdot 3$ & $40 \pm 5 \cdot 1$ & $160 \pm 8 \cdot 3$ & $141 \pm 12$ & $101 \pm 12$ \\
\hline Glycerol & $18 \cdot 4 \pm 5 \cdot 0$ & $56 \pm 5 \cdot 6$ & $38 \pm 12$ & $181 \pm 20$ & $163 \pm 19$ & $125 \pm 16$ \\
\hline DL- $\alpha$-Glycerophosphate & $13 \cdot 8 \pm 1 \cdot 8$ & $62 \pm 3 \cdot 2$ & $48 \pm 4 \cdot 3$ & $97 \pm 3 \cdot 5$ & $83 \pm 4 \cdot 6$ & $35 \pm 4.4$ \\
\hline D-Fructose & $13 \cdot 8 \pm 1 \cdot 8$ & $57 \pm 3 \cdot 6$ & $43 \pm 3 \cdot 5$ & $295 \pm 20$ & $281 \pm 21$ & $238 \pm 19$ \\
\hline Sorbitol & $13 \cdot 8 \pm 1.8$ & $57 \pm 3 \cdot 6$ & $43 \pm 3.5$ & $299 \pm 18$ & $285 \pm 19$ & $242 \pm 17$ \\
\hline Xylitol & $13.5 \pm 1 \cdot 8$ & $62 \pm 5 \cdot 7$ & $48 \pm 5 \cdot 8$ & $252 \pm 13$ & $238 \pm 13$ & $190 \pm 9 \cdot 1$ \\
\hline L-Alanine & $18 \cdot 4 \pm 5 \cdot 0$ & $56 \pm 5 \cdot 6$ & $38 \pm 12$ & $128 \pm 11$ & $110 \pm 13$ & $72 \pm 10$ \\
\hline L-Aspartate & $13 \cdot 3 \pm 1 \cdot 5$ & $67 \pm 4 \cdot 6$ & $54 \pm 3 \cdot 6$ & $74 \pm 9 \cdot 8$ & $61 \pm 9 \cdot 6$ & $7 \pm 6 \cdot 6$ \\
\hline L-Glutamate & $13 \cdot 9 \pm 1 \cdot 8$ & $61 \pm 3 \cdot 2$ & $47 \pm 3 \cdot 4$ & $64 \pm 11$ & $50 \pm 11$ & $3 \pm 7 \cdot 8$ \\
\hline L-Proline & $18 \cdot 9 \pm 4.9$ & $59 \pm 6 \cdot 3$ & $40 \pm 5 \cdot 1$ & $94 \pm 9 \cdot 4$ & $75 \pm 8 \cdot 6$ & $35 \pm 4 \cdot 0$ \\
\hline L-Threonine & $13.2 \pm 0.8$ & $61 \pm 6.5$ & $48 \pm 6 \cdot 2$ & $106 \pm 7 \cdot 4$ & $93 \pm 6 \cdot 9$ & $45 \pm 4 \cdot 6$ \\
\hline
\end{tabular}

Table 4. Formation of carbohydrate from various precursors by liver slices from male mice

The experimental conditions were as described for Table 1.

\begin{tabular}{|c|c|c|c|c|c|c|c|}
\hline & & & Glu & + glycoge & slices + med & $(\mu \mathrm{moles} / \mathrm{g}$ & wt./hr.) \\
\hline & & & $\begin{array}{r}\text { Incubat } \\
\text { sub }\end{array}$ & $\begin{array}{l}\text { without } \\
\text { ate }\end{array}$ & & ted with sul & rate \\
\hline $\begin{array}{l}\text { Substrate } \\
\text { added }\end{array}$ & $\begin{array}{l}\text { No. of } \\
\text { obser- } \\
\text { vations }\end{array}$ & $\begin{array}{c}\text { Initial } \\
\text { glucose }+ \\
\text { glycogen } \\
\text { ( } \mu \text { moles/g. } \\
\text { dry wt.) }\end{array}$ & Found & $\begin{array}{c}\text { Increase } \\
\text { over } \\
\text { initial }\end{array}$ & Found & $\begin{array}{c}\text { Increase } \\
\text { over } \\
\text { initial }\end{array}$ & $\begin{array}{c}\text { Extra carbo- } \\
\text { hydrate due } \\
\text { to added } \\
\text { substrate }\end{array}$ \\
\hline L-Lactate & 5 & $13 \cdot 1 \pm 5 \cdot 2$ & $59 \pm 16$ & $46 \pm 10$ & $112 \pm 12$ & $99 \pm 7 \cdot 4$ & $53 \pm 6 \cdot 3$ \\
\hline Pyruvate & 5 & $13 \cdot 1 \pm 5 \cdot 2$ & $59 \pm 16$ & $46 \pm 10$ & $108 \pm 14$ & $95 \pm 13$ & $49 \pm 18$ \\
\hline Glycerol & 8 & $7 \cdot 1 \pm 1 \cdot 0$ & $38 \pm 2.9$ & $31 \pm 2 \cdot 5$ & $117 \pm 4 \cdot 6$ & $110 \pm 4 \cdot 3$ & $79 \pm 5.6$ \\
\hline Dihydroxyacetone & 4 & $6 \cdot 2 \pm 1 \cdot 0$ & $33 \pm 2.4$ & $27 \pm 3 \cdot 3$ & $106 \pm 34$ & $100 \pm 34$ & $70 \pm 32$ \\
\hline D-Fructose & 4 & $6 \cdot 2 \pm 1 \cdot 0$ & $33 \pm 2 \cdot 4$ & $27 \pm 3 \cdot 3$ & $193 \pm 23$ & $187 \pm 31$ & $160 \pm 54$ \\
\hline Sorbitol & 4 & $6 \cdot 2 \pm 1 \cdot 0$ & $33 \pm 2 \cdot 4$ & $27 \pm 3 \cdot 3$ & $210 \pm 67$ & $204 \pm 18$ & $177 \pm 20$ \\
\hline Xylitol & 4 & $6 \cdot 2 \pm 1 \cdot 0$ & $33 \pm 2 \cdot 4$ & $27 \pm 3 \cdot 3$ & $215 \pm 15$ & $209 \pm 15$ & $182 \pm 17$ \\
\hline L-Alanine & 5 & $13 \cdot 1 \pm 5 \cdot 2$ & $59 \pm 16$ & $46 \pm 10$ & $87 \pm 12$ & $74 \pm 7 \cdot 9$ & $28 \pm 6.9$ \\
\hline L-Proline & 5 & $13 \cdot 1 \pm 5 \cdot 2$ & $59 \pm 16$ & $46 \pm 10$ & $80 \pm 8 \cdot 9$ & $67 \pm 4.4$ & $21 \pm 7 \cdot 1$ \\
\hline
\end{tabular}


Table 5. Formation of glucose by kidney-cortex slices from male and female mice

The experimental conditions were as described by Krebs et al. (1963). The results are given as means \pm S.E.M. The number of observations was three.

Glucose in medium ( $\mu$ moles/g. dry wt./hr.)

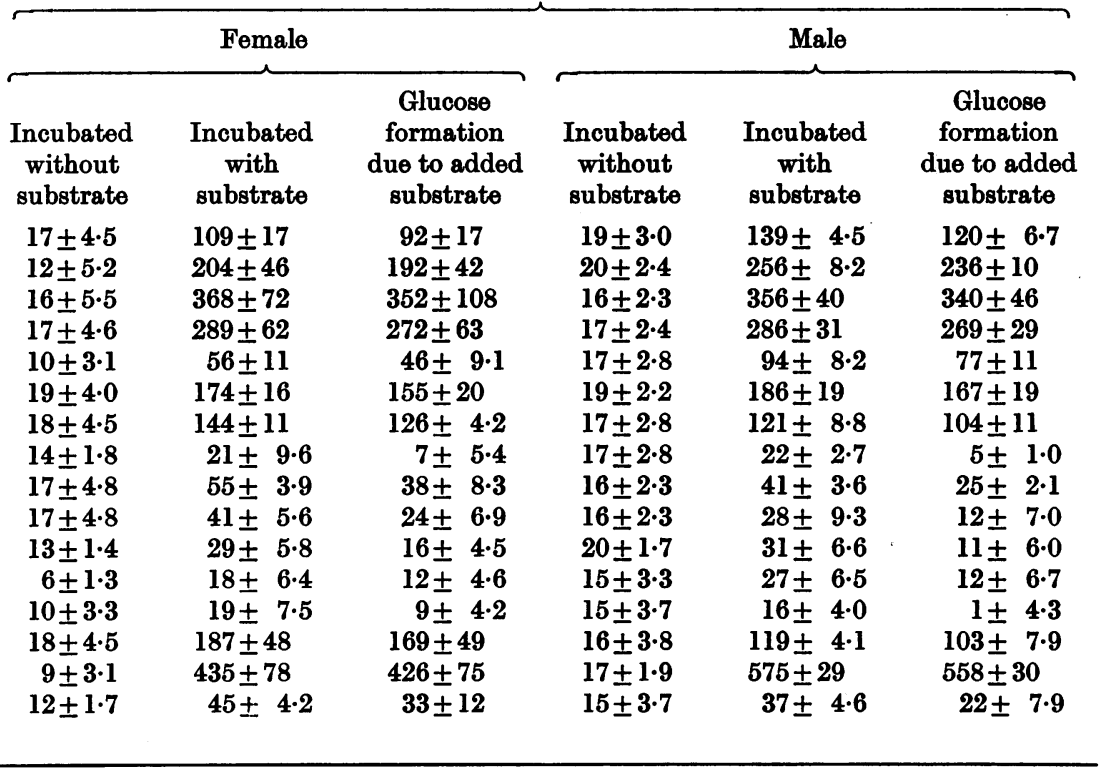

Table 6. Carbohydrate formation and nitrogen release by mouse-liver slices incubated without added substrate

The animals were kept on the standard diet and treated with phlorrhizin. For further experimental details see the text. Urea is expressed in ammonia equivalents. The time of incubation was $1 \mathrm{hr}$.

Substrate added

L-Lactate

Pyruvate

Fumarate

$\alpha$-Oxoglutarate

Propionate

L-Glutamate

L-Proline

L-Serine

L-Aspartate

L-Ornithine

L-Valine

L-Alanine

L-Isoleucine

Sorbitol

Glycerol

L-Sorbose

\begin{tabular}{ccc}
$\begin{array}{c}\text { Initial } \\
\text { glucose }+ \\
\text { glycogen } \\
(\mu \text { moles/g. }\end{array}$ & $\begin{array}{c}\text { After } \\
\text { dry wt.) }\end{array}$ & $\begin{array}{c}\text { Glucose+glycogen } \\
\text { ( } \mu \text { moles/g. dry wt./hr. })\end{array}$ \\
\cline { 2 - 3 } incubation & incubation \\
il & 63 & 52 \\
38 & 81 & 43 \\
25 & 57 & 32 \\
89 & 160 & 71 \\
8 & 31 & 23 \\
4 & 40 & 36 \\
5 & 32 & 27
\end{tabular}

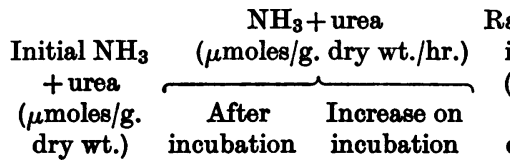

Ratio (increase in $\mathrm{N}$ release)/ (increase in glucose equivalents)

wt.) incubation incubation

$\begin{array}{llrl}82 & 286 & 204 & 3 \cdot 9 \\ 64 & 144 & 80 & 1 \cdot 9 \\ 89 & 154 & 65 & 2 \cdot 0 \\ 61 & 125 & 64 & 0 \cdot 9 \\ 92 & 193 & 101 & 4 \cdot 4 \\ 91 & 204 & 113 & 3 \cdot 1 \\ 71 & 123 & 52 & 1 \cdot 9\end{array}$

without added substrate was substantial but variable, ranging between 24 and $54 \mu \mathrm{moles} / \mathrm{g}$. dry wt./hr. It was accompanied by a nitrogen release that was also variable, but in six of the seven experiments where the ratio (increase in $\mathrm{N}$ release)/ (increase in glucose equivalents) was measured (Table 6) it was about 2 or higher. Since two molecules of amino acid could give one molecule of glucose, a value of 2 for this ratio would permit the assumption that amino acids were the chief precursor of the carbohydrate formed. Another possible precursor is glycerol, derived from the hydrolysis of fat. Glycerol might be expected to be a major precursor in animals given the lowcarbohydrate-high-fat diet. To test this the release of glycerol was measured from livers of mice given either the standard or a high-fat diet and treated with phlorrhizin. No substrate was added. Only small quantities of glycerol (3-4 $\mu$ moles/g. dry wt./hr.) were released aerobically and 5-6 $\mu$ moles/g. dry wt. $/ \mathrm{hr}$. anaerobically. As there is no gluconeogenesis whatsoever under anaerobic 
conditions without substrate, glycerol could be expected to arise instead of glucose. However, the quantities of glycerol found anaerobically are insufficient to account for a major proportion of the aerobic gluconeogenesis.

Gluconeogenesis in the livers of well-fed mice. In well-fed mice allowed unlimited access to the standard diet and not treated with phlorrhizin the initial concentrations of glucose plus glycogen in the liver were twice as high in animals killed at 9 a.m. as in those killed at 2 p.m. (Table 7). In liver slices from animals killed in the morning where the initial carbohydrate content was high there was little or no significant gluconeogenesis on incubation with substrate (Expts. 1 and 2 in Table 7). Addition of proline or alanine caused a loss of carbohydrate. Glycerol and D-glyceraldehyde were the only substrates to show a definite overall gain but this was small. In animals killed in the after- noon with lower initial concentrations of glucose plus glycogen added proline and alanine again caused a loss of carbohydrate. There was a small carbohydrate formation $(50 \mu \mathrm{moles} / \mathrm{g}$. dry wt.) with dihydroxyacetone. Glycerol, sorbitol, xylitol and D-glyceraldehyde gave 80-107 $\mu$ moles/g. dry wt. It was $134 \mu \mathrm{moles} / \mathrm{g}$. dry wt. with fructose. The effect of most added substrates was distinctly greater in the afternoon. Thus the livers of mice killed in the afternoon gave values midway between those of the starved and fed animals although they had full access to food.

Variations in the phlorrhizin treatment. To test the optimum conditions for the action of phlorrhizin with respect to the promotion of hepatic gluconeogenesis mice were killed 1, 2, 3, 4 and $6 \mathrm{hr}$. after the administration of phlorrhizin, and the gluconeogenic response of liver slices was measured with various substrates. Food was withheld after the

Table 7. Carbohydrate changes in liver slices from well-fed mice

Two sets of mice were used. They had unlimited access to the standard diet. Those used in Expts. 1 and 2 were killed at 9 a.m. and those used in Expts. 3 and 4 at 2 p.m. As the mice fed mainly at night those of Expts. 3 and $4 \mathrm{had}$ not eaten much during some $8 \mathrm{hr}$. before death; this is reflected by low initial values. Incubation was for $1 \mathrm{hr}$. The substrate concentration was $10 \mathrm{~mm}$ except for $\mathrm{D}$ - and L-glyceraldehyde where it was $5 \mathrm{~mm}$. The results are given as means \pm S.E.M. The number of observations was six.

Glucose + glycogen ( $\mu$ moles/g. dry wt./hr.)

\begin{tabular}{|c|c|c|c|c|c|c|c|}
\hline \multirow[b]{2}{*}{$\begin{array}{c}\text { Expt. } \\
\text { no. }\end{array}$} & \multirow[b]{2}{*}{ Substrate added } & \multirow[b]{2}{*}{$\begin{array}{c}\text { Initial } \\
\text { glucose }+ \\
\text { glycogen } \\
(\mu \text { moles } / \mathrm{g} . \\
\text { dry wt. })\end{array}$} & \multicolumn{2}{|c|}{$\begin{array}{c}\text { Incubated without } \\
\text { substrate }\end{array}$} & \multicolumn{3}{|c|}{ Incubated with substrate } \\
\hline & & & Found & $\begin{array}{c}\text { Increase } \\
\text { over } \\
\text { initial }\end{array}$ & Found & $\begin{array}{c}\text { Increase } \\
\text { over } \\
\text { initial }\end{array}$ & $\begin{array}{l}\text { Extra carbo- } \\
\text { hydrate due } \\
\text { to added } \\
\text { substrate }\end{array}$ \\
\hline 1 & $\begin{array}{l}\text { L-Lactate } \\
\text { Pyruvate } \\
\text { Glycerol } \\
\text { L-Proline } \\
\text { L-Alanine }\end{array}$ & $917 \pm 39$ & $922 \pm 64$ & $5 \pm 40$ & $\left\{\begin{array}{l}885 \pm 72 \\
898 \pm 64 \\
948 \pm 56 \\
837 \pm 53 \\
860 \pm 48\end{array}\right.$ & $\begin{array}{r}-32 \pm 42 \\
-19 \pm 38 \\
31 \pm 39 \\
-80 \pm 37 \\
-57 \pm 24\end{array}$ & $\begin{array}{r}-37 \pm 15 \\
-24 \pm 25 \\
26 \pm 16 \\
-85 \pm 30 \\
-62 \pm 27\end{array}$ \\
\hline 2 & $\begin{array}{l}\text { D-Glyceraldehyde } \\
\text { L-Glyceraldehyde } \\
\text { Dihydroxyacetone } \\
\text { D-Fructose } \\
\text { Sorbitol } \\
\text { Xylitol }\end{array}$ & $967 \pm 82$ & $1038 \pm 86$ & $71 \pm 8 \cdot 5$ & $\left\{\begin{array}{l}1096 \pm 101 \\
1020 \pm 88 \\
1044 \pm 99 \\
1069 \pm 126 \\
1011 \pm 102 \\
1036 \pm 128\end{array}\right.$ & $\begin{array}{r}129 \pm 30 \\
53 \pm 22 \\
77 \pm 16 \\
102 \pm 24 \\
44 \pm 23 \\
69 \pm 22\end{array}$ & $\begin{array}{r}58 \pm 28 \\
18 \pm 12 \\
6 \pm 13 \\
31 \pm 25 \\
28 \pm 24 \\
2 \pm 37\end{array}$ \\
\hline 3 & $\begin{array}{l}\text { L-Lactate } \\
\text { Pyruvate } \\
\text { Glycerol } \\
\text { L-Proline } \\
\text { L-Alanine }\end{array}$ & $359 \pm 31$ & $442 \pm 25$ & $83 \pm 41$ & $\left\{\begin{array}{l}429 \pm 34 \\
465 \pm 34 \\
522 \pm 40 \\
409 \pm 26 \\
396 \pm 30\end{array}\right.$ & $\begin{array}{r}70 \pm 48 \\
106 \pm 48 \\
163 \pm 53 \\
50 \pm 45 \\
37 \pm 34\end{array}$ & $\begin{array}{r}13 \pm 25 \\
23 \pm 17 \\
80 \pm 26 \\
-33 \pm 17 \\
-46 \pm 13\end{array}$ \\
\hline 4 & $\begin{array}{l}\text { D-Glyceraldehyde } \\
\text { L-Glyceraldehyde } \\
\text { Dihydroxyacetone } \\
\text { D-Fructose } \\
\text { Sorbitol } \\
\text { Xylitol }\end{array}$ & $396 \pm 61$ & $435 \pm 53$ & $39 \pm 20$ & $\begin{array}{l}542 \pm 57 \\
447 \pm 51 \\
485 \pm 61 \\
569 \pm 52 \\
536 \pm 51 \\
531 \pm 47\end{array}$ & $\begin{array}{r}146 \pm 18 \\
51 \pm 20 \\
89 \pm 38 \\
173 \pm 15 \\
140 \pm 19 \\
135 \pm 29\end{array}$ & $\begin{array}{r}107 \pm 16 \\
12 \pm 5 \\
50 \pm 17 \\
134 \pm 25 \\
101 \pm 17 \\
96 \pm 24\end{array}$ \\
\hline
\end{tabular}




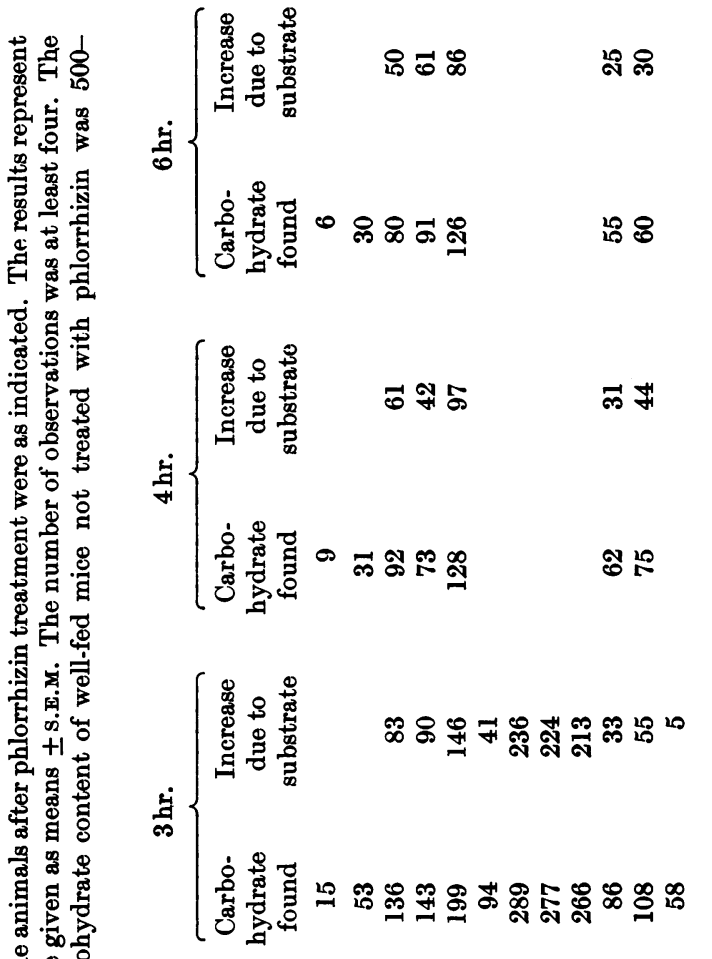

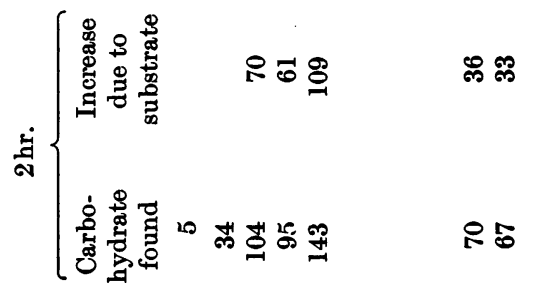

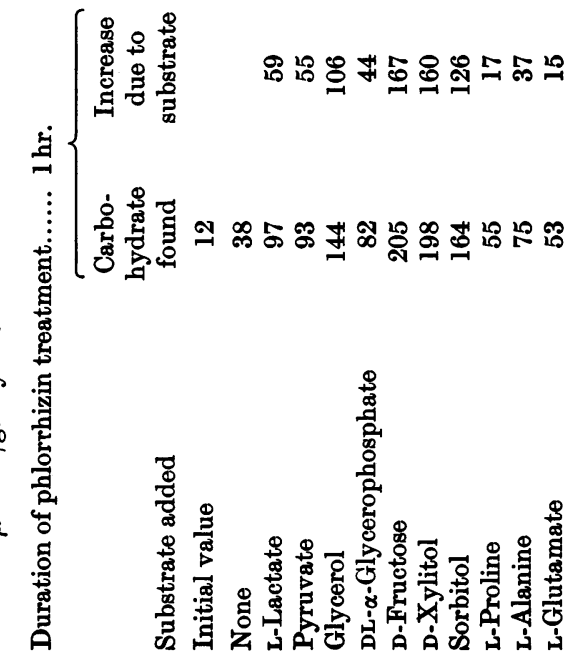

injection. As shown in Table 8, the depletion of the liver glycogen virtually reached a maximum within $1 \mathrm{hr}$. whereas the gluconeogenic response reached a peak after $3 \mathrm{hr}$. and then fell. In other experiments, not reported in detail, repeated phlorrhizin injections were given or phlorrhizin pellets ( $100 \mathrm{mg}$., made in a tablet press) were implanted subcutaneously between the shoulder blades under ether anaesthesia. The animals were fed on the standard diet. The implantation caused a glycosuria within $1 \mathrm{hr}$. that continued for more than 6 days. The carbohydrate content of the liver dropped within the first $5 \mathrm{hr}$. but rose to normal levels again within 2-3 days. Repeated phlorrhizin injections likewise did not prevent the extensive deposition of liver glycogen.

The effect of prolonged carbohydrate deficiency on the gluconeogenic capacity of the liver was tested in an experiment in which mice were kept for 11 days on a low-carbohydrate diet; $100 \mathrm{mg}$. of phlorrhizin was then implanted subcutaneously and the diet was continued. After another 4 days a subcutaneous injection of $10 \mathrm{mg}$. of phlorrhizin was given and food was withheld for $4 \mathrm{hr}$., when the mice were killed. The blood glucose values at this stage were 1.1-1.2 mM. The rates of gluconeogenesis observed in liver slices in these mice were no higher than those recorded in Table 1. Thus the liver reaches its maximal gluconeogenic capacity within $3 \mathrm{hr}$. of phlorrhizin treatment. It is not increased by a prolonged carbohydrate deficiency.

Effect of a low-carbohydrate-high-fat diet on gluconeogenesis. It was thought that the livers of animals fed on the high-fat diet might utilize glycerol as a specially effective precursor of carbohydrate. The diet was given for 2-4 days and the mice were treated with phlorrhizin (Table 9). As in previous experiments the liver from mice killed $1 \mathrm{hr}$. after the phlorrhizin injection gave lower values than those killed after $3 \mathrm{hr}$. All the substrates tested, including glycerol, gave lower values than those obtained with livers from mice given the standard diet. Gluconeogenesis in the absence of added substrates was strikingly low compared with the rates found with other diets.

Proportion of free glucose to total carbohydrate. As mentioned above, in all experiments free glucose and the sum of glucose and glycogen were measured. Unless special precautions were taken the concentration of free glucose was often between 17 and $35 \mathrm{mM}$, which is at least three times that of the glucose concentration in blood plasma. However, these high values were due to rapid post-mortem changes (see Table 10) and for this reason they are not recorded in the Tables. Liver frozen quickly with liquid-nitrogen-cooled clamps as described by Wollenberger, Ristau \& Schoffa (1960) contained much less free glucose than liver cooled as a lobe 
Table 9. Formation of carbohydrate from various precursors by liver slices from female mice fed on a high-fat diet

Except for the diet and the duration of the phlorrhizin treatment the experimental conditions were as described for Table 1. For the composition of the high-fat diet see the Experimental section. The results are given as means \pm s.E.M. The number of observations was four.

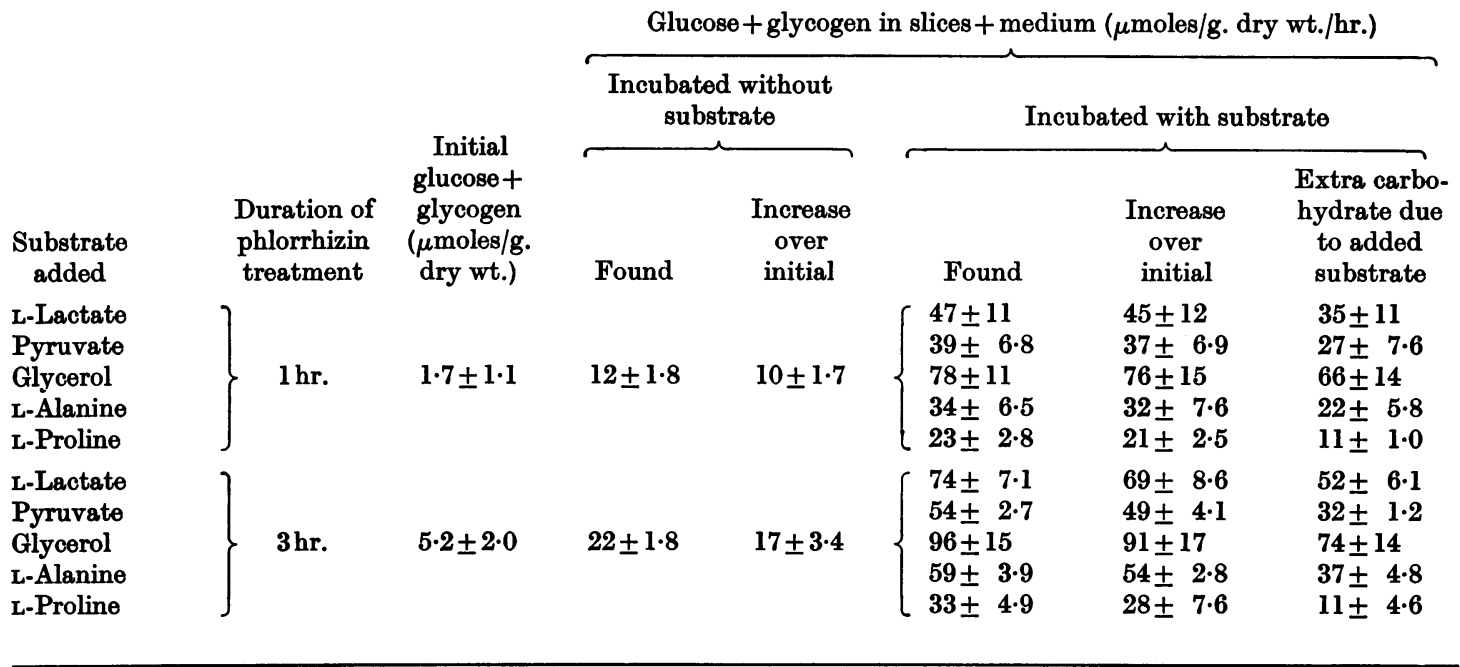

Table 10. Post-mortem increase in glucose content of mouse liver

Well-fed mice were used. Rapid freezing was carried out with metal clamps cooled in liquid $\mathrm{N}_{2}$ (see the text). Analyses were carried out in duplicate.

\begin{tabular}{clcc} 
Expt. no. & Post-mortem treatment & $\begin{array}{c}\text { Glucose } \\
\text { ( } \mu \text { moles/g. dry wt.) }\end{array}$ & $\begin{array}{c}\text { Total carbohydrate } \\
\text { (as glucose) } \\
\text { ( } \mu \text { moles/g. dry wt.) }\end{array}$ \\
\cline { 2 - 3 } & Rapid freezing & 19 & 669 \\
& Stored at $0^{\circ}$ for $10 \mathrm{~min}$. & 77 & 673 \\
& Stored at $20^{\circ}$ for $10 \mathrm{~min}$. & 106 & 665 \\
& Rapid freezing & 10 & 524 \\
& Stored at $20^{\circ}$ for $10 \mathrm{~min}$. & 88 & 513 \\
& Stored at $20^{\circ}$ for $20 \mathrm{~min}$. & 160 & 519 \\
& Stored at $20^{\circ}$ for $60 \mathrm{~min}$. & 221 & 563 \\
& Stored at $20^{\circ}$ for $160 \mathrm{~min}$. & 279 & 543
\end{tabular}

in isopentane at $-78^{\circ}$, or a lobe kept for $20 \mathrm{~min}$. on ice or for $5 \mathrm{~min}$. in situ before removal from the body. The livers of mice treated with phlorrhizin had glucose concentrations comparable with those of normal plasma (3-5 mM).

Gluconeogenesis in the liver of alloxan-diabetic mice. Diabetes was induced in female mice by a single subcutaneous injection of recrystallized alloxan monohydrate $[200 \mathrm{mg}$. $/ \mathrm{kg}$. body wt. in McIlvaine's (1921) phosphate-citric acid buffer, pH4.0]. The animals were maintained on the standard diet. During the first day their drinking water contained glucose $(5 \%, \mathrm{w} / \mathrm{v})$ since about $50 \%$ of the mice died without glucose feeding. Addition of glucose decreased the mortality rate to $10-20 \%$. About $\mathbf{9 0 \%}$ of the mice showed severe diabetes as indicated by glycosuria and blood sugar concentrations between 21 and $42 \mathrm{~mm}$. Results for the carbohydrate metabolism obtained with livers of diabetic mice treated with phlorrhizin are given in Table 11. The most striking difference between normal and diabetic liver is the high initial carbohydrate content of the slices after phlorrhizin treatment: in diabetic mice it was about ten times that in normal animals. Gluconeogenesis from endogenous substrates, i.e. the increase of carbohydrate in the absence of added substrate, was about twice that in normal animals (57-91 compared with 24-49 $\mu$ moles/g. dry wt.). The addition of the various substrates had about the same effects in normal and diabetic animals.

The carbohydrate content of the livers of diabetic 
Table 11. Formation of carbohydrate from various precursors by liver slices of alloxan-diabetic female mice

The experimental conditions were as described for Table 1 .

Glucose + glycogen in slices + medium ( $\mu$ moles/g. dry wt./hr.)

\begin{tabular}{|c|c|c|c|c|c|c|c|}
\hline \multirow[b]{2}{*}{ Substrate added } & \multirow[b]{2}{*}{$\begin{array}{l}\text { No. of } \\
\text { observa- } \\
\text { tions }\end{array}$} & \multirow[b]{2}{*}{$\begin{array}{c}\text { Initial } \\
\text { glucose }+ \\
\text { glycogen } \\
(\mu \text { moles/g. } \\
\text { dry wt.) }\end{array}$} & \multicolumn{2}{|c|}{$\begin{array}{c}\text { Incubated without } \\
\text { substrate }\end{array}$} & \multicolumn{3}{|c|}{ Incubated with substrate } \\
\hline & & & Found & $\begin{array}{c}\text { Increase } \\
\text { over } \\
\text { initia] }\end{array}$ & Found & $\begin{array}{l}\text { Increase } \\
\text { over } \\
\text { initial }\end{array}$ & $\begin{array}{c}\text { Extra carbo- } \\
\text { hydrate due } \\
\text { to added } \\
\text { substrate }\end{array}$ \\
\hline L-Lactate & 6 & $125 \pm 59$ & $216 \pm 75$ & $91 \pm 31$ & $267 \pm 48$ & $142 \pm 26$ & $51 \pm 25$ \\
\hline Pyruvate & 6 & $125 \pm 59$ & $216 \pm 75$ & $91 \pm 31$ & $318 \pm 62$ & $193 \pm 28$ & $102 \pm 32$ \\
\hline Glycerol & 6 & $125 \pm 59$ & $216 \pm 75$ & $91 \pm 31$ & $301 \pm 63$ & $176 \pm 34$ & $85 \pm 13$ \\
\hline $\begin{array}{l}\text { DL- } \alpha \text {-Glycero- } \\
\text { phosphate }\end{array}$ & 3 & $81 \pm 68$ & $138 \pm 71$ & $57 \pm 3 \cdot 4$ & $182 \pm 65$ & $101 \pm 5 \cdot 2$ & $44 \pm 6.9$ \\
\hline D-Fructose & 3 & $81 \pm 68$ & $138 \pm 71$ & $57 \pm 3.4$ & $394 \pm 64$ & $313 \pm 33$ & $256 \pm 34$ \\
\hline Sorbitol & 3 & $81 \pm 68$ & $138 \pm 71$ & $57 \pm 3.4$ & $391 \pm 76$ & $310 \pm 17$ & $253 \pm 17$ \\
\hline L-Alanine & 6 & $125 \pm 59$ & $216 \pm 75$ & $91 \pm 31$ & $285 \pm 52$ & $160 \pm 20$ & $69 \pm 22$ \\
\hline L-Aspartate & 3 & $81 \pm 68$ & $138 \pm 71$ & $57 \pm 3 \cdot 4$ & $120 \pm 58$ & $39 \pm 11$ & $-18 \pm 14$ \\
\hline L-Glutamate & 3 & $81 \pm 68$ & $138 \pm 71$ & $57 \pm 3.4$ & $131 \pm 68$ & $50 \pm 0.7$ & $-7 \pm 2.7$ \\
\hline L-Proline & 6 & $125 \pm 59$ & $216 \pm 75$ & $91 \pm 31$ & $239 \pm 64$ & $114 \pm 21$ & $23 \pm 19$ \\
\hline
\end{tabular}

animals not treated with phlorrhizin was 449$792 \mu$ moles/g. dry wt., which is in the same range as that found in normal animals. On incubation without substrate there was again a large increase in the carbohydrate content (average $125 \mu \mathrm{moles} / \mathrm{g}$. dry wt./hr.) but the formation of new carbohydrate on incubation with various substrates was smaller than in the livers of diabetic animals treated with phlorrhizin.

These experiments confirm the increased rates of gluconeogenesis in the diabetic liver already well established by many different procedures (for earlier references see Friedmann, Goodman \& Weinhouse, 1965). Under the test conditions endogenous material provided the main precursors. The fact that phlorrhizin is less effective in depleting the alloxan-diabetic liver within $3 \mathrm{hr}$. than the normal liver may be due to the high glucose content of the diabetic tissues. If the glucose space of the mouse is $25 \%$ of the body weight the glucose content of the diabetic tissues could be almost as great as the glucose stored as liver glycogen.

The glycogen content of livers of alloxan-diabetic mice was not higher than that of control animals, in contrast with the rise often observed in alloxandiabetic rats (Tuerkischer \& Wertheimer, 1948; Morita \& Orten, 1950; Beloff-Chain et al. 1956).

\section{DISCUSSION}

Precursors in hepatic gluconeogenesis. The rates of gluconeogenesis observed in slices of livers depleted of glycogen by phlorrhizin were much higher than any previously recorded value on liver slices (see Ashmore, Wagle \& Uete, 1964). Nevertheless, the rates for most substrates (lactate, pyruvate, fructose, sorbitol, dihydroxyacetone and alanine) were no more than about $50 \%$ of the rates observed in the perfused rat liver (Exton \& Park, 1965; Hems et al. 1966, and unpublished work). The only exception was glycerol, which gave a higher value in mouse-liver slices than in perfused rat liver. No data are available for the perfused mouse liver but it is very unlikely that the glucogenic capacity of the intact mouse liver is lower than that of rat liver.

Unexpected is the limited range of precursors that were gluconeogenic in liver slices. Of the amino acids only alanine, serine, threonine and proline, and of the non-nitrogenous precursors only lactate, pyruvate, fructose, D-glyceraldehyde, dihydroxyacetone, propionate and several polyols (glycerol, sorbitol and xylitol), were definitely glucogenic. Absent from the list of ready precursors in liver slices are glutamate, aspartate and the intermediates of the tricarboxylic acid cycle. The low or negligible rates obtained with these substances are unexpected considering that (1) they readily form oxaloacetate in liver homogenate or in isolated mitochondria, (2) a rapid oxidation of succinate is known to occur in slices (see Rosenthal, 1937) and (3) oxaloacetate formed intramitochondrially is an obligatory intermediate in the formation of glucose from lactate and pyruvate. Since 
all the enzymes and cofactors required for gluconeogenesis are present the failure of the substances to act as precursors suggests either an inhibition of key enzymes by the added precursors or the existence of specific permeability barriers. Work in progress favours the latter explanation.

With respect to gluconeogenesis from amino acids and the intermediates of the tricarboxylic acid cycle liver and kidney cortex appear to act somewhat complementarily. Alanine and serine, which readily react in the liver, are not effective in the kidney (Table 5 and unrecorded observations). Glutamate, aspartate, ornithine and the intermediates of the tricarboxylic acid cycle, which do not readily react in the liver, are good gluconeogenic precursors in kidney cortex. An exception is proline, which reacts readily in both tissues. Lactate, pyruvate, dihydroxyacetone, D-glyceraldehyde and the polyols react in both liver and kidney cortex (see Krebs \& Lund, 1966).

Gluconeogenesis in well-fed liver. Gluconeogenesis fromall precursors, including the polyols, dihydroxyacetone, D-glyceraldehyde and fructose, was greatly diminished in the livers of well-fed mice. The nature of this 'inhibition' is uncertain. Factors that may play a role are inhibitions of enzymes initiating the metabolic sequences such as the kinases converting hexoses into their phosphates, or allosteric inactivation of pyruvate carboxylase (see Krebs, 1964), or accelerated degradation of triose phosphate by an increased activity of pyruvate kinase (Krebs \& Eggleston, 1965). The last-named reaction would shift the readily reversible steps between triose phosphate and phosphoenolpyruvate in favour of the formation of pyruvate, followed by complete oxidation or conversion into fat if pyruvate carboxylase is inactive.

Effect of phlorrhizin. Gluconeogenesis in the liver reached maximal values when mice were given an injection of phlorrhizin and starved for $3 \mathrm{hr}$. At this time the liver was almost completely depleted of glycogen. The glucogenic capacity of the liver is thus related to the level of the glycogen store rather than, directly, to the nature of the diet. However, there was no strict parallelism between glycogen depletion and the rate of gluconeogenesis in that glycogen depletion on phlorrhizin treatment was almost maximal within $1 \mathrm{hr}$. whereas the gluconeogenic capacity did not reach its maximum until $3 \mathrm{hr}$. after the injection of phlorrhizin (Table 8). The time lag in reaching the maximum gluconeogenic capacity was relatively short, and the promptness of the reaction to glycogen depletion suggests that the adjustment of the liver to carbohydrate synthesis is largely due to the control of enzymes by feedback effects rather than to changes in the rate of enzyme synthesis. If the latter were involved, they must be very rapid, being completed within $3 \mathrm{hr}$. The low-carbohydrate diet, which increases the gluconeogenic capacity of rat kidney cortex, had no effect on mouse liver.

Unlike rat kidney, mouse kidney did not change its gluconeogenic capacity in response to a lowcarbohydrate diet (observations not reported in full). The difference between the two species may be connected with the fact that the rates in mouse kidney cortex are under all circumstances very high, a fact presumably connected with the considerably higher metabolic rate of the mouse.

Comparison of $\mathrm{D}$ - and $\mathrm{L}$-lactate. In the living rat given D- and L-[ $\left.{ }^{14} \mathrm{C}\right]$ lactate Hoberman \& D'Adamo (1960) found that L-lactate was incorporated nine times more rapidly into glycogen than D-lactate. According to Table 1 the rate of synthesis of carbohydrate in mouse-liver slices was 4.5 times faster from L-lactate than from D-lactate.

Sex differences. Sex differences, as observed for the gluconeogenesis in mouse liver, have already been reported for various liver enzymes, namely glucose 6-phosphate dehydrogenase and 6-phosphogluconate dehydrogenase (Glock \& McLean, 1953), a cholinesterase (Brown \& Harrison, 1951) and $\beta$-glucuronidase (Fishman \& Farmelant, 1953). In every case the activity of the female liver was greater.

The authors are indebted to the Pharmacy of the Radcliffe Infirmary, Oxford, for making phlorrhizin tablets. This work was supported by U.S. Public Health Service Grant no. AN08715.

\section{REFERENCES}

Ashmore, J., Wagle, S. R. \& Uete, T. (1964). Advanc. Enzyme Regul. 2, 101.

Bach, S. J. \& Holmes, E. G. (1937). Biochem. J. 81, 89. Beloff-Chain, A., Bovet, D., Catanzaro, R., Chain, E. B., Kohn, R., Masi, I. \& Pocchiari, F. (1956). Sel. sci. Pap. Ist. sup. Sanit. 1, 304.

Brown, L. M. \& Harrison, M. F. (1951). Nature, Lond., 168, 83.

Buchanan, J. M., Hastings, A. B. \& Nesbett, F. B. (1942). J. biol. Chem. 145, 715.

Conway, E. J. (1962). Microdiffusion Analysis and Volumetric Error. London: Crosby Lockwood and Son Ltd.

Cori, C. F. \& Cori, G. T. (1929). J. biol. Chem. 81, 389.

Cori, C. F. \& Shine, W. M. (1936). J. biol. Chem. 114, xxi.

Cross, M. C. A. \& Holmes, E. G. (1937). Brit.J. exp. Path. $18,370$.

Deutsch, W. (1936). J. Physiol. 87, 56 P.

Exton, J. H. \& Park, C. R. (1965). J. biol. Chem. 200, PC955.

Fishman, W. H. \& Farmelant, M. H. (1953). Endocrinology, $52,536$.

Friedmann, B., Goodman, E. H., jun. \& Weinhouse, S. (1965). J. biol. Chem. 240, 3729.

Garland, P. B. \& Randle, P. J. (1962). Nature, Lond., 196, 987. 
Glock, G. E. \& McLean, P. (1953). Biochem. J. 55, 400. Hanzlik, P. J., Lehman, A. J., van Winkle, W., jun. \& Kennedy, N. K. (1939). J. Pharmacol. 67, 114.

Hems, R., Ross, B. D., Berry, M. N. \& Krebs, H. A. (1966). Biochem. J. 101, 284.

Hoberman, H. D. \& D'Adamo, A. F., jun. (1960). J. biol. Chem. 235, 514.

Krebs, H. A. (1964). Proc. Roy. Soc. B, 159, 545.

Krebs, H. A., Bennett, D. A. H., de Gasquet, P., Gascoyne, T. \& Yoshida, T. (1963). Biochem. J. 86, 22.

Krebs, H. A. \& de Gasquet, P. (1964). Biochem. J. 93, 149.

Krebs, H. A., Dierks, C. \& Gascoyne, T. (1964). Biochem. $J .93,112$.

Krebs, H. A. \& Eggleston, L. V. (1965). Biochem. J. 94, 3c.
Krebs, H. A. \& Henseleit, K. (1932). Hoppe-Seyl. Z. 210, 33.

Krebs, H. A. \& Lund, P. (1966). Biochem. J. 98, 210.

McIlvaine, T. C. (1921). J. biol. Chem. 49, 183.

Morita, Y. \& Orten, J. M. (1950). Amer. J. Physiol. 161, 545.

Rosenthal, O. (1937). Biochem. J. 31, 1710.

Takane, R. (1926). Biochem. Z. 171, 403.

Tuerkischer, E. \& Wertheimer, E. (1948). J. Endocrin. 5, 229.

Warburg, O., Gawehn, K. \& Geissler, A. W. (1956). Z. Naturf. 11b, 658.

Weissberger, L. H. (1941). J. biol. Chem. 139, 543.

Wollenberger, A., Ristau, O. \& Schoffa, G. (1960). Pflüg. Arch. ges. Physiol. 270, 399. 